Cadernos de Semiótica Aplicada

Vol. 5.n.2, dezembro de 2007

\title{
ANÁLISE SEMIÓTICA DO POEMA “OS SAPOS”, DE MANUEL BANDEIRA
}

\author{
A SEMIOTIC ANALYSIS OF “OS SAPOS”, BY MANUEL BANDEIRA
}

Dayane Celestino de Almeida USP - Universidade de São Paulo

Resumo: Ao longo de sua carreira, Manuel Bandeira escreveu vários poemas que podem ser considerados "poéticas", ou seja, eles tratam do "fazer poesia", ora dizendo para quê a poesia serve, ora dizendo como ela deve ser. Este trabalho apresenta uma análise de um desses poemas - "Os Sapos" - sob a perspectiva da semiótica francesa.

Palavras-chave: semiótica; poesia; Greimas; Manuel Bandeira

Abstract: Throughout his career, Manuel Bandeira wrote some poems that talk about "making poetry", saying either what the poetry is for or how it should be. This paper presents an analysis of one of these poems - "Os Sapos" - from the French semiotics point of view.

Keywords: semiotics; poetry; Greimas; Manuel Bandeira

"Os Sapos" foi publicado em 1919 no livro Carnaval. Tal livro pode ser visto como predecessor dos livros seguintes, uma vez que já se anunciam nele alguns elementos que estariam mais tarde em Ritmo Dissoluto (1924) ou Libertinagem (1930). Apesar de geralmente ainda ser considerado pela crítica como parte da "primeira fase" da obra de Bandeira, Carnaval pode ser visto como uma espécie de "obra de transição". Nesse contexto, "Os Sapos" soa como um primeiro movimento em direção ao que o poeta (e a poesia brasileira como um todo) alcançaria nos anos seguintes. Não há dúvida do caráter metalingüístico desse texto, que procura discutir como a poesia não deveria ser. O poema se inicia com uma cena em que alguns sapos saem da penumbra e se põem a conversar. Tomam a palavra o sapo-boi, o sapo-tanoeiro, o sapo-pipa - metáforas para o que podemos chamar de "tipos" de poetas. A metade das estrofes do poema representa a fala do sapo-tanoeiro (parnasiano aguado), que passa a descrever o seu cancioneiro, a sua poética. Durante essa fala são descritos preceitos da poética parnasiana. Por fim, a situação descrita é a do sapocururu, que se destaca dos demais (longe dessa grita (...) / e solitário é) e pode ser visto como 
o poeta não-parnasiano. Finda esta breve introdução, passaremos agora à análise do poema, a fim de demonstrar os recursos utilizados na construção do sentido.

Para tanto, iniciaremos por um estudo do plano do conteúdo, passando, ao final, a uma descrição do plano da expressão. Vejamos, a seguir, a transcrição do poema:

\section{Os Sapos}

Enfunando os papos, Saem da penumbra, Aos pulos, os sapos. A luz os deslumbra.

Em ronco que aterra, Berra o sapo-boi:

— "Meu pai foi à guerra!"

— "Não foi!" — "Foi!" — "Não foi!".

O sapo-tanoeiro,

Parnasiano aguado,

Diz: - "Meu cancioneiro

É bem martelado.

Vede como primo

Em comer os hiatos!

Que arte! E nunca rimo

Os termos cognatos.

O meu verso é bom

Frumento sem joio.

Faço rimas com

Consoantes de apoio.

Vai por cinqüenta anos

Que lhes dei a norma:

Reduzi sem danos

A formas a forma.

Clame a saparia

Em críticas céticas:

Não há mais poesia,

Mas há artes poéticas...
Urra o sapo-boi:

— "Meu pai foi rei!" — "Foi!"

— "Não foi!" — "Foi!" — "Não foi!".

Brada em um assomo

O sapo-tanoeiro:

- A grande arte é como

Lavor de joalheiro.

Ou bem de estatuário.

Tudo quanto é belo,

Tudo quanto é vário,

Canta no martelo".

Outros, sapos-pipas

(Um mal em si cabe),

Falam pelas tripas:

— "Sei!" - "Não sabe!" - "Sabe!".

Longe dessa grita,

Lá onde mais densa

A noite infinita

Verte a sombra imensa;

Lá, fugido ao mundo,

Sem glória, sem fé,

No perau profundo

E solitário, é

Que soluças tu,

Transido de frio,

Sapo-cururu

Da beira do rio...

Iniciaremos abordando o nível narrativo, conforme o percurso gerativo do sentido, proposto por A. J. Greimas. Podemos dividir o poema em duas partes: a primeira, que vai do início até a estrofe 11 e a segunda, a partir da estrofe 12 (onde se inicia a menção ao sapo-cururu). Começando pela primeira parte, observamos um enunciado de estado no qual um sujeito está em conjunção com um determinado objeto-valor. Já fazendo uma ligação com o nível discursivo, podemos identificar esse sujeito como os atores sapo-tanoeiro, sapo-boi e sapo-pipa. O objeto-valor, por sua vez, é a poesia que eles defendem e com a qual estão em conjunção. Toda a fala do sapo-tanoeiro é repleta de elogios a essa poesia. O resultado do seu fazer é exaltado e valorizado, ou seja, trata-se de um julgamento positivo. Neste sentido, 
dizemos que o sujeito foi manipulado por um destinador que passou a ele seus valores e que o fez-fazer (ou seja, fez escrever o seu cancioneiro). Esse actante destinador é aqui representado pelo que podemos chamar "sociedade literária" de uma determinada época. O sujeito quer entrar em conjunção com valores existentes no seu grupo social. Recapitulando, na ordem canônica da narrativa, podemos dizer que um destinador (a "sociedade literária") manipula um destinatário (os sapos - metáfora do poeta parnasiano) que passa a querer estar em conjunção com determinados valores inscritos num objeto (a poesia, o cancioneiro). Após a ação pressuposta, ocorre a etapa do julgamento, no qual volta o destinador ${ }^{1}$, sancionando o sujeito positivamente (elogios, exaltação). Buscando seu objeto-valor, o sujeito realiza, na verdade, a integração com os valores de uma determinada sociedade, de um determinado grupo. Conforme Barros (2003, p. 23), quando o sujeito de estado é representado pelo mesmo ator que o sujeito do fazer, pode-se falar em um programa narrativo de aquisição reflexiva, que também recebe o nome de apropriação. O sujeito adquire, por si mesmo, os valores almejados. Neste caso, a integração.

$\mathrm{Na}$ segunda parte, quando entra em cena o sapo-cururu, o que temos é um outro enunciado de estado, no qual o sujeito não aceitou a manipulação do destinador (ao contrário do que havia ocorrido na primeira parte) e não busca integração com seus valores. Isso pode ser corroborado no nível discursivo: longe dessa grita, lá, fugido ao mundo, sem fé, solitário, etc. Não aceitando o contrato proposto pelo destinador, o sujeito nega, assim, a integração. Nesse ponto, é possível depreender a oposição semântica básica, no nível fundamental: integração versus transgressão.

O segundo verso da penúltima estrofe diz que o sapo-cururu está Sem glória, sem fé. A partir da expressão sem glória, podemos inferir que o sujeito (ator sapo-cururu) não realizou a ação que o levaria à conjunção com os valores propostos pelo destinador, mas ele realizou alguma ação, que está sendo julgada, aqui, como inglória. Podemos dizer, portanto, que o destinador (representado agora pelo narrador) sanciona a ação transgressora do sujeito negativamente. Ao sujeito transgressor não cabe outra coisa senão ficar sem glória, sem fé, solitário, no perau profundo, transido de frio. Na verdade, esse é um primeiro destinador, representante da "República (oficial) dos poetas", guardião dos valores parnasianos dominantes, mas há também um segundo destinador, representante dos valores da transgressão/solidão, que, ao contrário do primeiro, sanciona positivamente o sapo-cururu.

A oposição no nível fundamental, da qual falamos acima, pode ser representada pelo quadrado semiótico a seguir:

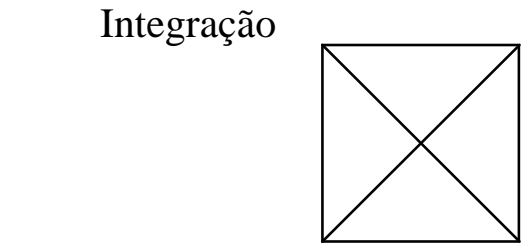

Não-Transgressão
Transgressão

Não-Integração

Figura 1

\footnotetext{
${ }^{1} \mathrm{O}$ actante destinador é quem julga o fazer do sujeito na etapa da sanção. No texto de bandeira, o sujeito do fazer e o destinador correspondem ao ator "sapo". Podemos, portanto, falar em um sincretismo actancial, uma vez que o mesmo ator ocupa duas posições actanciais diferentes.
} 
Segundo Tatit (2001, p. 16-25) podemos também falar em termos de continuidade versus descontinuidade, sendo a continuidade afirmada pelo sujeito "parnasiano" (o sapo-tanoeiro) e a descontinuidade, pelo sujeito "não-parnasiano" (o sapocururu), por não agir "parnasianamente", não aceitando, a manipulação do destinador. Há, portanto, uma ruptura com os valores pré-estabelecidos, por parte do sapo-cururu.

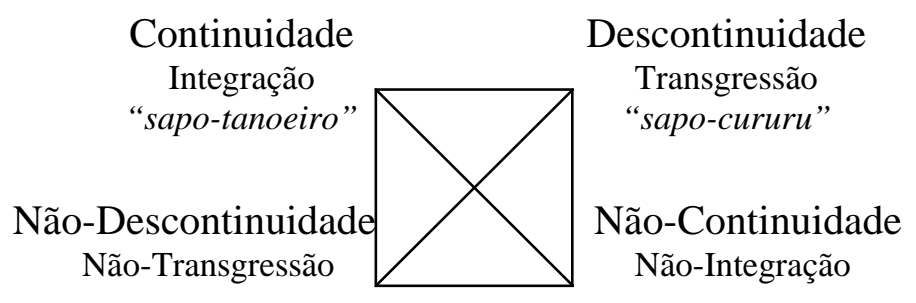

Figura 2

Em termos tensivos, ainda segundo Tatit (2001, p. 177), a continuidade pode estar situada numa área de relaxamento (continuação da continuação). Um dos elementos do texto que corroboram essa afirmação é a estrofe Vai por cinqüienta anos / Que lhes dei a norma / Reduzi sem danos / A formas a forma, em que o sujeito afirma que os procedimentos que utiliza vêm de longa data e que ele continua certa tradição. Já a descontinuidade, como uma ruptura, representa uma parada da continuação, inserindo-se, portanto, numa área de contenção. Essas relações podem ser visualizadas, recorrendo uma vez mais a Tati (2001), por meio do quadrado semiótico abaixo:
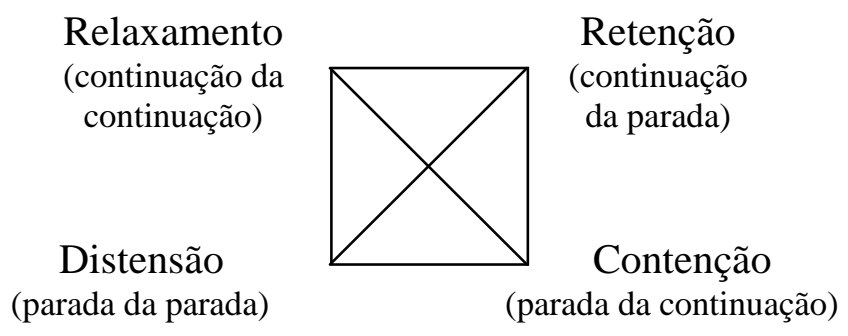

Figura 3

O sujeito da primeira parte (os sapos, excetuando-se o sapo-cururu), que está numa zona de relaxamento e em conjunção com seu objeto-valor, é um sujeito da satisfação (Cf. BARROS, 2001, P. 64). O sujeito satisfeito é aquele resultante do seguinte arranjo modal: querer-ser, crer-ser e saber-poder-não-ser em conjunção com o objeto. A paixão da satisfação pela obtenção do objeto desejado pode ser denominada alegria ou felicidade. É fácil perceber, no nível discursivo, a felicidade e a auto-satisfação do sujeito. Vejamos alguns exemplos:
a) Um mal em si cabe
b) Enfunando ${ }^{2}$ os papos
c) Vede como primo / Em comer os hiatos

\footnotetext{
${ }^{2}$ Considerando que um dos significados para enfunar é, segundo o dicionário Aurélio, envaidecer.
} 
d) Que arte! (...)

e) O meu verso é bom / Frumento sem joio (...)

O sujeito da segunda parte (sapo-cururu), por sua vez, configura-se como um sujeito que ainda não está em conjunção com o objeto-valor ("poesia-transgressão"). Podemos fazer tal afirmação, visto que o sujeito está sem glória, sem fé, solitário e transido de frio. Em termos modais, portanto, esse é um sujeito que quer-ser e que crê-não-ser em conjunção com o objeto; ele nega a integração, mas ainda não está em conjunção plena com a transgressão. Essa análise nos leva a rever e reformular um dos quadrados semióticos apresentados anteriormente, no qual enquadramos o sapo-cururu na transgressão/descontinuidade. Na verdade, sua posição no percurso ainda é a da não-integração, apesar de estar "caminhando" para a transgressão. Vejamos abaixo o referido quadrado semiótico, agora já alterado:

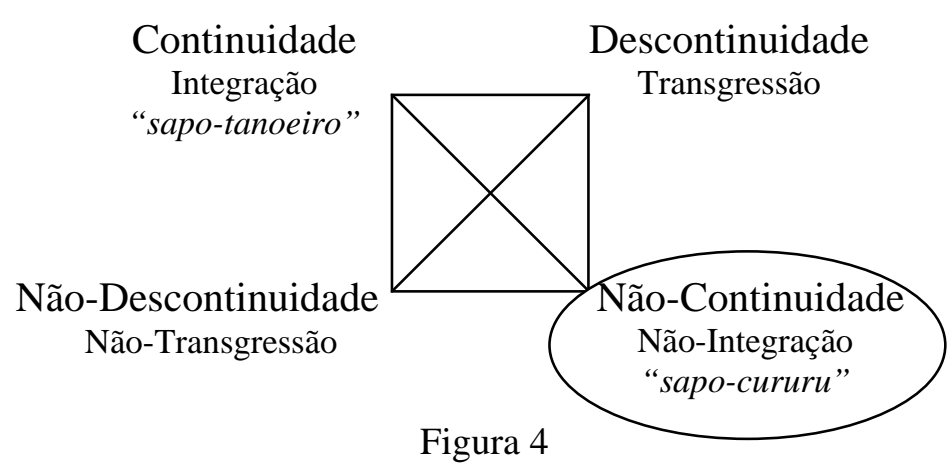

Voltando ao estado passional desse sujeito, verificamos, portanto, que, sendo aquele que quer-ser, mas não-crê-ser e que está em disjunção com o objeto-valor, ele é um sujeito da aflição ou da insegurança, que se encontra em um estado de espera-tensa. Exemplos no nível discursivo que corroboram esse estado podem ser arrolados:

a) Lá, fugido ao mundo / Sem glória, sem fé

b) Es solitário é

c) Que soluças tu

d) Transido de frio

Uma vez analisados os níveis fundamental e narrativo, cabe-nos, agora, dar atenção ao nível discursivo. Em termos da sintaxe discursiva, verifica-se, logo num primeiro contato, que "Os Sapos" começa com a presença de um narrador em terceira pessoa que, em alguns momentos, dá a palavra às personagens (que passam a interlocutores). Na primeira estrofe, ocorre uma debreagem enunciva de pessoa e de espaço (Saem da penumbra / Aos pulos, os sapos) e uma debreagem enunciativa de tempo (agora), uma vez que ela é indicada pelos verbos no presente do indicativo (saem, deslumbra). Essa presentificação do narrado cria o efeito de proximidade entre o que se narra e o tempo da narração e simula "uma concomitância entre o tempo da narração e o dos acontecimentos narrados" (FIORIN, 2005, p. 63). Em seguida, na segunda estrofe, o narrador anuncia o sapo-boi e delega a ele a palavra, ou seja, ocorre uma debreagem de segundo grau ou interna. Nesse ponto, o sapo-boi realiza uma debreagem enunciva (Meu pai (ele) foi (passado) à guerra (lá)), seguida de uma resposta 
do seu interlocutário: — "Não foi!" — "Foi!" — "Não foi!". Para indicar as debreagens de segundo grau, as aspas e o travessão foram os recursos utilizados neste texto.

A partir da terceira estrofe, o narrador inscreve no discurso o sapo-tanoeiro e, novamente, cede a palavra. A fala desse ator permanece desde a estrofe 3 até a 7 e trata-se de uma debreagem interna enunciativa de pessoa e tempo, como podemos ver pelos verbos no presente (tempo: agora), pelos verbos em primeira pessoa (pessoa: eu), pronomes em primeira pessoa (v. $11 \underline{\mathrm{meu}}$ cancioneiro, v. 17: $\underline{\mathrm{meu}}$ verso). Na oitava estrofe, volta a fala do sapo-boi, obedecendo aos mesmos mecanismos que já vimos na estrofe 2 . Nas estrofes 9 e 10, reaparece a fala do sapo-tanoeiro, mas dessa vez em uma debreagem enunciva de pessoa (conforme os verbos em terceira pessoa: A grande arte $\underline{\boldsymbol{e}}$ como (...) / Tudo quanto $\underline{e}$ belo / Tudo quanto $\underline{e}$ vário, / Canta no martelo. O tempo, porém, continua no sistema enunciativo (conforme observamos por meio dos verbos é e canta, que estão no presente do indicativo). Interessante observar que, nessa estrofe, o interlocutor faz uma explicação comparativa entre a poesia e outras artes, tendo, portanto, como meta, um maior efeito de objetividade; por isso, a escolha de não se marcar no enunciado, fazendo uso da debreagem enunciva de pessoa. É como se o interlocutor quisesse convencer o interlocutário de que a sua explicação não está ligada a intuições ou a sua opinião particular, mas sim que é uma verdade. Além disso, o uso do verbo ser (A grande arte é como) no presente omnitemporal tem a mesma função, uma vez que tal tipo de presente é usado para o anúncio do que se pretende como "verdadeiro".

Nova debreagem interna é realizada na estrofe 11, dando voz, desta vez, ao sapo-pipa, que realiza uma debreagem enunciativa: "Sei!"; "Não sabe!"; "Sabe!". A partir da estrofe 12, volta o narrador e não há mais debreagens de segundo grau até o fim. Agora, a debreagem, assim como no início, é enunciativa para o tempo, indicado pelos verbos no presente. A debreagem espacial é enunciva e o espaço do lá é figurativizado por Longe dessa grita, Lá, no perau profundo, Da beira do rio. Quanto à categoria de pessoa, há uma diferença em relação à primeira parte em que aparece o narrador, pois agora ele se dirige ao sapo-cururu como tu (Que soluças tu), instaurando, dessa forma, um eu e um $t u$, numa debreagem enunciativa. Com isso, percebemos que o narrador mantém um distanciamento dos demais sapos, enquanto se aproxima do sapo-cururu. Esse recurso ajuda a depreender qual é a posição do enunciador com relação a esses dois atores e seus valores. A aproximação do narrador leva a deduzir que a posição euforizada pelo enunciador é a do sapo-cururu. Assim, tudo que no enunciado é dito pelo sapo-tanoeiro num tom exaltado - que, num primeiro momento, parecem ser valores afirmados - é na verdade negado pela enunciação.

Isso configura, pois, o efeito de ironia, que é o que ocorre quando se afirma algo no enunciado e se nega na enunciação. Pode-se dizer que a ironia é a grande "chave" para a compreensão do tema de "Os Sapos", pois o enunciado afirma um tipo de fazer poético que a enunciação nega. Com esse procedimento, o texto trata, portanto, de como a poesia não deve ser, euforizando uma poética "livre das amarras", em oposição à poética parnasiana. Fiorin (2005, p. 79) comenta que, no caso de um não-acordo entre enunciado e enunciação, o discurso $\mathrm{X}$ deve ser entendido como não X. A ironia pode, também, ser depreendida pelo tom satírico presente ao longo do texto. A própria figura dos sapos como metáfora dos poetas já causa um certo humor e sugere ao enunciatário que desconfie das afirmações que estão por vir, tomando-as em segundo grau. Outra marca da enunciação no enunciado ${ }^{3}$ que nos faz ler a fala do sapo-tanoeiro como introdutora de preceitos poéticos disfóricos está logo na terceira estrofe, quando esse ator aparece pela primeira vez e é descrito pelo narrador como parnasiano aguado, expressão que transmite uma avaliação do narrador. É importante, ainda,

\footnotetext{
${ }^{3}$ Segundo Fiorin (2005, p. 78), quando há uma avaliação do narrador, a expressão ou palavra em questão é vista como um elemento de enunciação enunciada.
} 
ressaltar que a própria delegação de voz ao sapo-tanoeiro por parte do narrador já constitui um mecanismo de afastamento do que vai ser dito. Ao fazer isso, o narrador se retira e é como se dissesse: "não sou eu quem está dizendo isso". Portanto, essa também é uma marca que nos faz perceber a posição no enunciador.

Outro elemento que intensifica a ironia é a paródia. Nesse poema, o texto "Profissão de Fé", , de Olavo Bilac é parodiado. Tal texto diz: Imito o ourives quando escrevo; em "Os Sapos", temos: A grande arte é como / Lavor de joalheiro. Sobre esta paródia, o próprio Bandeira escreveu, em Itinerário de Pasárgada, o seguinte:

A propósito desta sátira, devo dizer que a dirigi contra certos ridículos do pósparnasianismo. É verdade que nos versos A grande arte é como / Lavor de joalheiro parodiei o Bilac da 'Profissão de fé' (Imito o ourives quando escrevo). Duas carapuças havia, endereçada uma ao Hermes Fontes, outra ao Goulart de Andrade. O poeta das Apoteoses, no prefácio ao livro, chamara a atenção do público para o fato de não haver nos seus versos rimas de palavras cognatas; Goulart de Andrade publicara uns poemas em que adotara a rima francesa com consoante de apoio (assim chamam os franceses a consoante que precede a vogal tônica da rima), mas nunca tendo ela sido usada em poesia de língua portuguesa, achou o poeta que devia alertar o leitor daquela inovação e pôs sob o título dos poemas a declaração entre aspas: "Obrigado à consoante de apoio". Bandeira (1984, p. 61)

A paródia tem um papel decisivo na construção do sentido nesse texto. Discini (2004, p. 26) nos explica que "a paródia contém uma diferença em relação ao texto-base, na medida em que subverte seu enunciado e desqualifica sua enunciação, propondo uma outra enunciação substituta, contrária, diferente". É exatamente isso que ocorre em "Os Sapos", onde a enunciação substituta - que podemos chamar de não-parnasiana - ganha destaque em detrimento da primeira enunciação - a parnasiana.

Na paródia, um outro sentido é construído para a mesma história do texto base. $\mathrm{O}$ fato de se comparar o ato de escrever ao trabalho do ourives ou joalheiro é o mesmo nos dois textos, porém eles expressam coisas diferentes em cada um deles. No texto-base, imitar o ourives é uma ação tida como elevada, ao passo que na paródia, essa preocupação é exposta como sendo "ridícula", sem valor. Isso vai ao encontro do que diz Discini $(2004$, p. 27$)$ ao afirmar que a paródia simula que aceita o texto-base para destruí-lo.

No âmbito da semântica discursiva, "Os Sapos" apresenta o tema da poética ou do "fazer poesia" e é um texto predominantemente figurativo. Figuras como parnasiano, cancioneiro, rimas, verso, poesia e artes poéticas constituem o percurso figurativo do "fazer poesia". Mas não é de qualquer poesia que trata o texto, mas sim de uma poesia específica, presa às formas e às normas, mais precisamente da poesia parnasiana. Esse percurso figurativo da poesia parnasiana é formado por meio de figuras como parnasiano aguado, cancioneiro bem martelado, comer os hiatos, termos cognatos, verso bom, frumento sem joio, consoantes de apoio, norma, forma, lavor de joalheiro, bem de estatuário, martelo. A presença de palavras eruditas, difíceis ou pouco utilizadas permeando todo o poema também contribui para a constituição desse percurso figurativo, uma vez que o uso de tais palavras era uma prática comum entre os poetas parnasianos. Exemplos de tais vocábulos, em "Os Sapos" são: enfunando, penumbra, primo, frumento, clame, lavor, estatuário, vário, verte, perau, transido. É possível depreender, portanto, uma crítica aos principais dogmas parnasianos. Tais dogmas foram arrolados por Brandão (1992, p. 122):

\footnotetext{
${ }^{4}$ A transcrição completa do poema pode ser vista nos "Anexos".
} 
(...) a perfeição: (Meu cancioneiro / É bem martelado), o purismo (O meu verso é bom / Frumento sem joio), o preciosismo (Que arte! E nunca rimo / Os termos cognatos), o enrijecimento formal (Vai por cinqüenta anos / Que lhes dei a norma: / Reduzi sem dano / A formas a forma.), a supervalorização das poéticas (Não há mais poesia / mas há artes poéticas), a minúcia do trabalho poético (A grande arte é como / Lavor de joalheiro), (...), etc. (grifo nosso).

Pensando nas pessoas projetadas pela sintaxe discursiva, vemos que elas são tematizadas como poetas e figurativizadas como sapos: sapo-boi, sapo-tanoeiro, sapo-pipa, sapo-cururu.

O sapo-cururu figurativiza o poeta não-parnasiano. O tema da negação do parnasianismo é dado pelo percurso figurativo formado por longe dessa grita, lá, fugido ao mundo, transido de frio, sapo-cururu / da beira do rio, solitário. Interessante notar que os sapos escolhidos para figurativizar o poeta parnasiano são tipos menos conhecidos - o que vai ao encontro da prática parnasiana de utilizar palavras pouco comuns. Já o sapo-cururu é um tipo bastante conhecido dentro da cultura popular. Não podemos deixar de notar a intertextualidade com a cantiga de roda "Sapo-cururu" que transcrevemos abaixo:

\author{
Sapo-cururu \\ Da beira do rio \\ Quando o sapo canta, \\ Ó maninha, \\ É que sente frio. \\ A mulher do sapo \\ Deve estar lá dentro \\ Fazendo rendinha, \\ Ó maninha, \\ Para o casamento
}

Os dois primeiros versos da cantiga (Sapo-cururu / Da beira do rio) são exatamente os dois últimos do poema. Além disso, a cantiga diz que o sapo sente frio e o poema diz que o sapo está transido de frio. A intertextualidade é importante fator de construção do sentido. Conforme Discini (2004, p. 11), "o texto-base entra como condição de construção de sentido do discurso da variante intertextual”. A utilização de uma espécie simples e conhecida de sapo e a intertextualidade com a cantiga de roda remetem à simplicidade e ao cotidiano - dois pontos muito presentes dentro do que se configuraria, mais tarde, como a poética modernista. A utilização de uma figura tão grotesca quanto um sapo vai ainda ao encontro da poética de Manuel Bandeira, uma vez que o autor defendia que a poesia "está em tudo - tanto nos amores como nos chinelos, tanto nas coisas lógicas como nas disparatadas" (BANDEIRA, 1984, p. 19).

Já que tocamos no ponto intertextualidade, cabe destacar o verso Frumento sem joio. Tal verso estabelece uma relação intertextual com a parábola bíblica "O joio e o trigo" (Mateus 13:24-30). Em tal parábola, um semeador planta o trigo, mas o joio cresce também em seu campo. Ele deixa que ambos cresçam juntos para, só na hora da colheita, fazer a separação. Ao dizer que seu verso é frumento sem joio, o interlocutor ressalta o fato de seu verso ser "puro" e de qualidade. Levando em conta as considerações feitas por Zilberberg (2004), podemos dizer que na parábola há uma tendência em direção à mistura, enquanto no 
poema a ênfase é colocada na triagem. Triagem e mistura operam no eixo da extensidade $\mathrm{e}^{5}$ tal intervalo de referência pode ser chamado de [puro $v s$ impuro]. Considerando, portanto, o poema em seu conjunto, reparamos que há, no eixo da extensidade, uma contraposição entre a valorização parnasiana do raro, do exclusivo, do puro (resultantes da operação de triagem) e a valorização (que será modernista) do "comum", do coloquial (resultante da operação de mistura). Tal valorização parnasiana está, ainda, presente próprio vocábulo "parnasiano", uma vez que ele faz referência ao Monte Parnaso ${ }^{6}$, lembrando uma noção de isolamento e de exclusividade dos parnasianos, que estariam no alto, longe dos "simples mortais" e mais próximo dos Deuses. Graficamente, é possível representar as valorizações da seguinte forma:

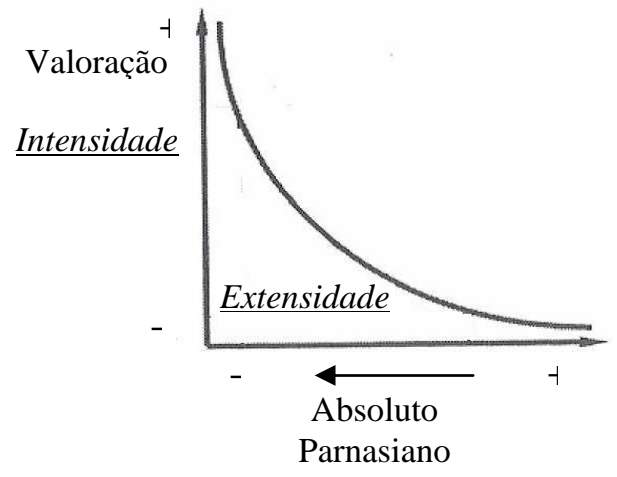

Figura 5

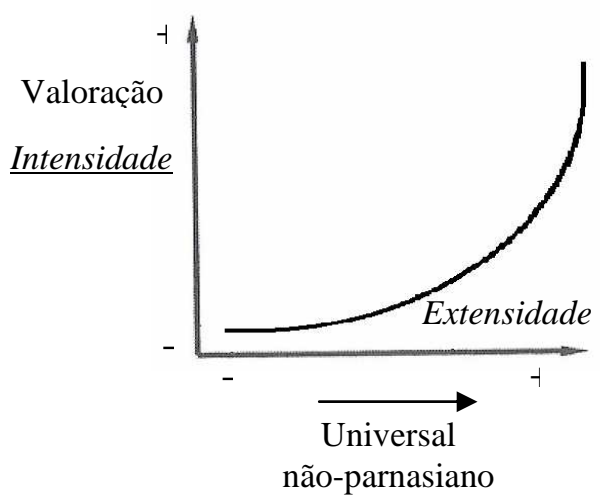

Figura 6

Quanto ao espaço, o lugar onde se encontra o sapo-cururu é um lugar distante. Como está distante dos outros, dos parnasianos (longe dessa grita), ele representa o lugar da não-integração e é figurativizado pelas suas características: longe, perau profundo. O espaço representa também o espaço do lirismo, em oposição à primazia da técnica dos parnasianos, como podemos ver pela seguinte descrição:

\section{Lá onde mais densa A noite infinita \\ Verte a sombra imensa;}

Quanto ao tempo, percebemos a figurativização do tempo passado (na fala do sapo-boi). Esse tempo passado é tematizado como um tempo heróico e figurativizado por meio de guerra e de rei (Meu pai foi rei ...). A insistência do sapo-boi nesse episódio gera o efeito de sentido de importância do passado, mais precisamente, da poesia do passado, nesse poema. Essa forte ligação com a tradição não permite uma ruptura nem a experimentação de novas formas artísticas. Isso pode ser corroborado pelos versos Vai por cinqüenta anos / que lhes dei a norma. Ou seja, é apresentado, aqui, o traço sêmico da duratividade; uma duratividade temporal e também de tempo de conjunção com esse tipo de poesia. Essa

\footnotetext{
${ }^{5}$ Cf. Ivã C. Lopes (2005 p. 206): “A extensidade mostra-se na tensão contínua entre o uno e o múltiplo (...). Quanto à intensidade, o que varia é a medida, seja da tonicidade - numa linha que vai do átono ao tônico -, seja do andamento - num contínuo que vai do mais lento ao mais rápido”.

${ }^{6}$ Parnaso é um monte situado na Grécia. Segundo a mitologia, lá ficavam o deus Apolo e as Musas, divindades inspiradoras das artes.
} 
indicação temporal ajuda a pensar na poética parnasiana como "acostumada", mecanizada, pois desde há muito apenas segue uma norma. A esse respeito, Garbuglio (1987, p. 34) afirma que, de acordo com "Os Sapos", os parnasianos "não mais faziam que repetir o que ouviam sem originalidade ou novidade, um hábito sovado (...)".

Os verbos que se relacionam ao ato de falar contribuem para figurativizar essa diferença entre o poeta-parnasiano e o não-parnasiano, ou entre a integração e a transgressão (a direção à transgressão). O sapo-boi, o sapo-tanoeiro e o sapo-pipa têm suas falas apresentadas pelos verbos: berra, diz, urra, brada e falam, ao passo que o sapo-cururu apenas soluça (Que soluças tu). Ou seja, o único ator contra as convenções é o único que apenas soluça, o que é muito mais fraco do que as outras formas de se expressar que aparecem. $\mathrm{O}$ soluçar representa, assim, o isolamento daqueles que são contra os valores vigentes.

Algumas figuras do poema criam um efeito de sinestesia. A oposição luz "versus" penumbra (estrofe 1) está relacionada ao sentido da visão. Já todos os verbos que têm a ver com a fala (urra, brada, berra), mais a expressão falam pelas tripas e o substativo grita (ou seja, barulho, gritaria) despertam o sentido da audição. Na última estrofe, por fim, frio desperta uma sensação tátil. Falam pelas tripas é uma expressão que lembra uma outra expressão utilizada correntemente: falam pelos cotovelos, que, por sua vez, constitui um exemplo do que é conhecido como catacrese (espécie de metáfora simples e utilizada corriqueiramente, não original). O jogo lingüístico aqui foi pegar parte de uma expressão comumente utilizada (falam pelas) e completá-la com uma palavra de outro contexto - tripas - que, no caso, reforça o efeito de humor no texto e "casa" com a sonoridade.

Um último ponto a abordar em relação ao nível discursivo o das isotopias. Os diversos tipos de sapos do texto de Bandeira apresentam claramente o traço /não-humano/, mas podemos ler o texto como uma história de poetas, ou seja, de humanos. Isso é possível graças a lexemas presentes no texto que apresentam o traço /humano/, como, por exemplo, os verbos de que tratamos há pouco (falar, dizer, soluçar). Sapo não fala, não diz, não soluça, mas os homens sim. Por outro lado, homens não berram, nem urram, mas animais sim, o que animaliza novamente o humano. Esse jogo entre humano e não-humano ajuda a reforçar uma imagem pejorativa do poeta parnasiano.

Voltando à isotopia do "humano", destacamos, ainda, os lexemas cancioneiro, parnasiano, poesia, arte, verso, rimas, ou seja, aqueles que já havíamos relacionado com o percurso figurativo do fazer poético, o que faz bastante sentido, visto que a poesia é algo humano. Quando iniciamos a leitura do poema, antes de qualquer aparição de lexemas com o traço /humano/, pensamos apenas em uma história sobre sapos. No momento em que, porém, aparecem as palavras com o traço /humano/, passamos imediatamente a um novo plano de leitura. Assim, nesse caso, tais lexemas funcionam como desencadeadores de isotopia.

Neste ponto, podemos fazer uso de um quadrado semiótico por meio do qual é possível homologar as várias relações que vimos nesse texto, nos três níveis do percurso gerativo do sentido: 


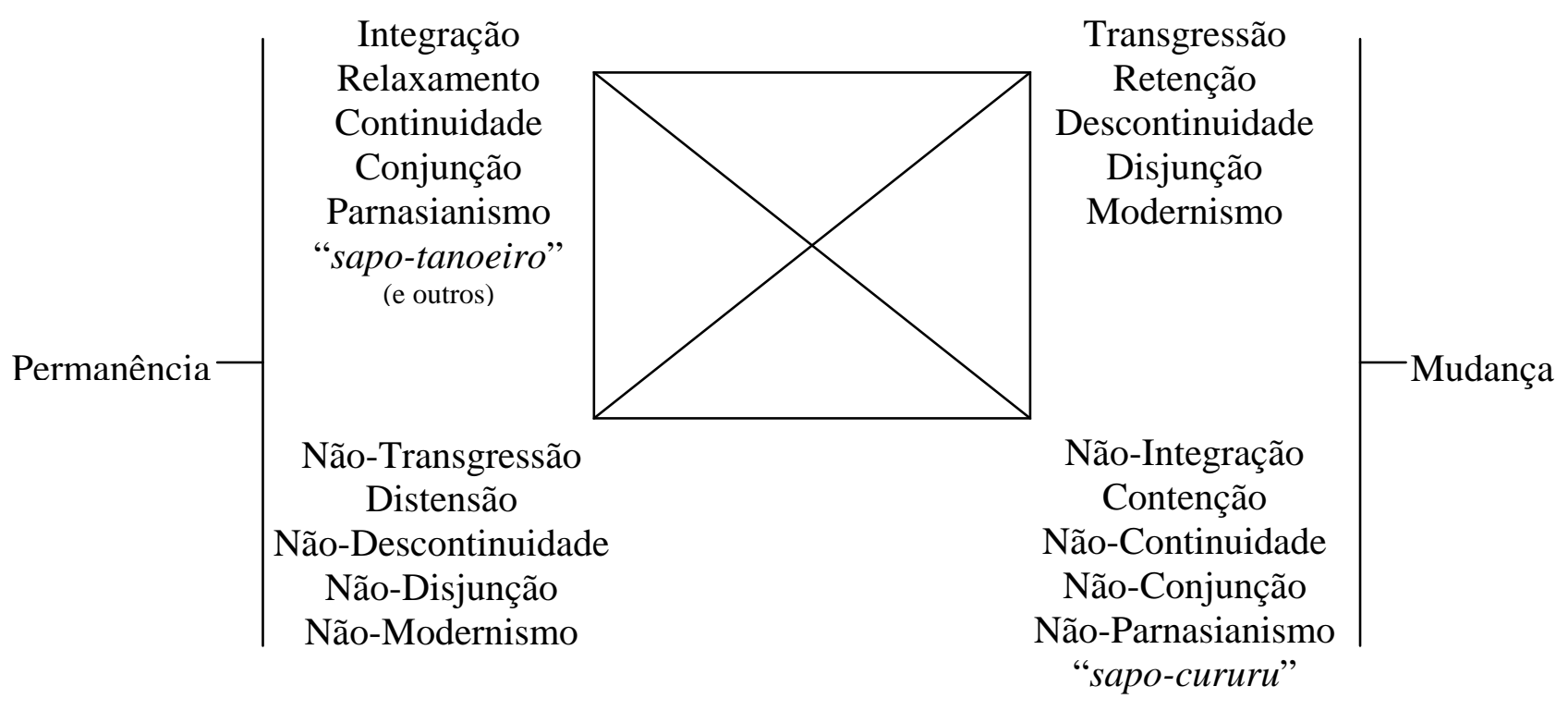

Figura 7

Sobre a aspectualização no poema, gostaríamos de tecer um breve comentário. Levando em conta a noção de limites e limiares (ZILBERBERG, 2007), podemos dizer que o aspecto predominante nesse poema é o durativo, ou seja, relacionado aos limiares. Do ponto de vista paradigmático, o que se vê é uma alternância entre duratividade e pontualidade. Relacionados à duratividade estão, por exemplo: a forma enfunando (gerúndio; indica continuidade); os verbos no presente que indicam um hábito (e não uma ação pontual), como em $O$ meu verso é bom, Faço rimas com, Tudo quanto é belo, E nunca rimo, Vede como primo; a expressão Vai por cinqüenta anos, que indica duração temporal e continuidade da ação, etc. No âmbito da pontualidade, destacamos os verbos no presente relacionados a ações pontuais que simulam a ocorrência de tais ações no momento da enunciação, tais como: berra, diz, urra, brada, falam. Por fim, podemos destacar o verbo soluçar (Que soluças tu) portando um aspecto iterativo.

Passamos, nesse momento, à descrição do plano da expressão, procurando verificar de que maneira sua estruturação auxilia a engendrar os efeitos de sentido no texto e quais são as relações entre expressão e conteúdo. O poema possui quatorze estrofes, sendo treze quadras e um terceto. A distribuição é a seguinte: as sete primeiras estrofes são de quatro versos; a oitava, de três versos e as seis seguintes, de quatro versos novamente. Quanto à métrica, todos os versos são de cinco sílabas (redondilha menor), com exceção do último verso da penúltima estrofe, com seis sílabas. Esse verso é justamente o que diz E solitário, é , sendo solitário no que diz respeito à métrica.

O ritmo do poema é, em geral, irregular. As regularidades, que descreveremos mais adiante, encontram-se apenas em algumas estrofes. Abrindo um parêntese, gostaríamos de ressaltar que foi em Carnaval que Bandeira deu os primeiros passos ao encontro de um ritmo "livre". Segundo Goldstein (2005, p. 17), em Carnaval "Formalmente, predomina a regularidade, com pitadas de inovação rítmica anunciadora do modernismo (...). A inovação rítmica é ilustrada pelo famoso 'Os Sapos' (...)".

Quanto às rimas, o poema segue um esquema $\mathrm{ABAB}$, que é interrompido apenas no único terceto existente (AAA, estrofe 8). 
Na primeira estrofe, o par de palavras que rima nos versos 1 e 3 constitui um par mínimo (papos / sapos), o que reforça o "eco" produzido. Na rima dos versos 2 e 4 não encontramos um par mínimo, mas podemos verificar que mais da metade dos sons das palavras são repetidos: penumbra / deslumbra, fato que, juntamente com a presença da vogal [u] nasalizada, parece produzir uma maior ressonância. Se tomarmos a cena apresentada nessa primeira estrofe, ou seja, os sapos saindo da penumbra aos pulos, podemos imaginar que eles emitem algum som ao fazê-lo. Portanto, é como se o poema recuperasse esse som por meio da ressonância intensificada que acabamos de descrever e que é, também, reforçada pela presença das palavras enfunando e saem, ambas primeiras palavras de dois versos seguidos e

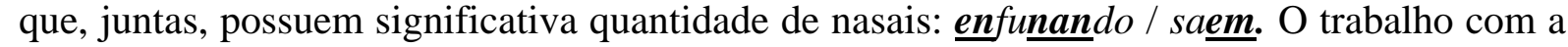
sonoridade nessa primeira estrofe ainda continua. A aliteração do [p] (papos, penumbra, pulos, sapos) faz lembrar realmente o movimento descrito na cena: o de sapos pulando. Esse movimento de "sobe e desce" é também simulado no que diz respeito ao uso das vogais, considerando-se a grande quantidade de ocorrências da vogal [u] (vogal alta) ao longo da estrofe, ocorrendo sempre imediatamente após (ou no máximo mais uma vogal após) ou antes de um [a] (vogal baixa), como em enfunando, da penumbra, aos pulos, a luz e deslumbra. Dessas palavras, duas estão na rima (versos 2 e 4), o que fortalece a relação entre elas. $O$ último ponto a mencionar no que tange à sonoridade dessa estrofe é o fato de existir uma "rima interna" nos versos 3 e 4, que transcrevemos abaixo:

Aos pulos, os sapos.

A luz os deslumbra.

Ainda na primeira estrofe, em termos da sintaxe, predomina a ordem inversa nos três primeiros versos que juntos formam uma só proposição. A ordem natural desses versos seria: Os sapos saem da penumbra. Enfunando os papos e Aos pulos podem aparecer em diversas ordens. Normalmente, porém, na linguagem corrente, apareceriam juntos ao final da sentença, da seguinte forma: Os sapos saem da penumbra aos pulos, enfunando os papos. A sintaxe "entrecortada" é o que permite colocar papos e sapos na rima. Note-se, ainda, que os dois constituintes "acessórios" (enfunando os papos e aos pulos) ficaram alocados nos versos ímpares. Os constituintes fora de ordem realçam a impressão que se tem dos pulos dos sapos, conforme já explicamos com relação à sonoridade.

Passando para a segunda estrofe, notamos que os versos pares têm sua rima formada por um ditongo ([oj]). Este ditongo aparece, ainda, outras vezes ao longo do poema, numa seqüência que simula uma "conversa" entre sapos:

Em ronco que aterra,

Berra o sapo-boi:

— "Meu pai foi à guerra!"

— "Não foi!" — "Foi!" — "Não foi!".

A rima dos versos ímpares, por sua vez, é formada pela seqüência de sons erra. Além disso, a primeira palavra do segundo verso - berra - "rima com a rima", além de constituir um par mínimo com guerra. Constatamos também a aliteração da consoante [X] (ronco, aterra, berra, guerra), justamente na estrofe que anuncia o "ronco" de um sapo. O som dessa consoante aproxima-se ao barulho de um ronco. A seqüência no último verso dessa estrofe ("Não foi!" — "Foi!" — "Não foi!") é um diálogo e nos faz lembrar o coaxo de dois sapos. Esse "coaxar" também é dado pelo ritmo. Observe-se que o último verso, assim como a 
metade do penúltimo, é formado por monossílabos tônicos. Um último ponto a ressaltar com relação a essa estrofe é que a quantidade de consoantes é exatamente a mesma nos quatro versos: há cinco consoantes em cada um deles. Sob um outro ponto de vista, podemos agrupar esses versos dois a dois, pois os dois primeiros juntos formam uma proposição e os dois últimos formam o diálogo. Além disso, o substantivo ronco pode ser relacionado semanticamente ao verbo berra. Quanto à sintaxe, novamente há uma inversão, visto que a ordem natural da língua portuguesa é Sujeito + Verbo. Aqui, porém, ocorre o contrário: Berra o sapo-boi. A inversão também pode estar sendo utilizada como um recurso que exemplifica a poética da qual se fala, uma vez que esse uso é visto, na maioria das vezes, em situações formais e em contextos poéticos.

$\mathrm{Na}$ terceira estrofe, todos os versos terminam em $-o$. e a diferença, com relação às vogais, entre os versos pares e ímpares se dá na penúltima sílaba de cada palavra, com [ej] para os versos ímpares e [a] para os pares. É nessa estrofe que tem início a fala do sapotanoeiro, que, segundo o dicionário Houaiss, é o mesmo que sapo-martelo, dizendo que seu cancioneiro é "bem martelado". Martelado, aqui, significa que é bem "medido" no sentido de que as rimas, a métrica e outros elementos beiram a perfeição. O interessante é verificar que é exatamente isso que ocorre ao longo de "Os Sapos", com suas rimas e métrica regulares, bem como com outras regularidades no plano sonoro. Como já visto, não há uma regularidade rítmica no poema. Nesse sentido, essa estrofe destaca-se, pois três de seus quatro versos compartilham o mesmo ritmo. $\mathrm{O}$ que se vê, portanto, é um recurso do plano da expressão ajudando a ressaltar algo do plano do conteúdo (nesse caso o fato de o cancioneiro ser bem martelado). Vemos que as palavras que compõem a rima nos versos ímpares são substantivos que se relacionam também semanticamente, uma vez que o sapo-tanoeiro é aquele que escreve o cancioneiro. Sintaticamente, há também uma semelhança, uma vez que ambos ocupam a posição de núcleo do sujeito das frases que formam. Esses vocábulos relacionam-se também com o outro substantivo da estrofe: parnasiano, já que o sapo-tanoeiro é uma metáfora do poeta parnasiano.

Na quarta estrofe, o sapo-tanoeiro (parnasiano aguado) diz: Vede como primo /

Em comer os hiatos. Justamente no verso em que diz que prima em comer os hiatos, ele "come" o hiato da palavra hiato, se considerarmos a métrica do poema todo (cinco sílabas). Vejamos:

\section{Em / co / me/ros / hia / tos.}

Esse procedimento é utilizado outras vezes no poema, como, por exemplo, no verso que segue, da nona estrofe (observe-se a sílaba em negrito):

\section{La /vor / de /joa / lhei / ro}

Ainda na quarta estrofe, há uma correspondência fonética no início dos dois primeiros versos, dada pelas palavras como e comer. A consoante velar [k] aparece em todos os versos (5 ocorrências no total) e a seqüência [ko], em três dos quatro versos, formando uma rima interna. Destacamos, ainda, a significativa quantidade de ocorrências da consoante [m] nessa estrofe: Vede como primo / Em comer os hiatos! / Que arte! E nunc a rimo / Os termos cognatos. Nessa estrofe também há correspondências semânticas ou sintáticas entre as palavras que compõem a rima. Observando os versos pares, notamos que tanto primo, quanto rimo são verbos, ou seja, são núcleos do predicado ao qual pertencem. Por sua vez, os componentes da rima dos versos pares exercem, ambos, a função de objeto direto e, 
semanticamente, estão relacionados por terem em comum o fato de se referirem à linguagem (hiatos-termos cognatos).

$\mathrm{Na}$ estrofe de número 5 existe uma grande quantidade de ocorrência de nasais (consoantes e vogais) em todos os versos, conforme destacamos na transcrição abaixo:

\section{O meu verso é bom \\ Frumento sem joio. \\ Faço rimas com \\ Consoantes de apoio.}

Note-se que essas nasais aparecem justamente nas palavras que se referem ao verso do sapo-tanoeiro e que valorizam suas qualidades. Todos os substantivos dessa estrofe estão relacionados de alguma maneira. Três deles estão ligados à poesia (verso-rimasconsoantes). Os outros dois (frumento e joio) estão em oposição e a expressão frumento sem joio é que qualifica o verso do qual se fala. Cada par de versos constitui uma proposição, sendo que a segunda parte (os versos pares) sempre completa o sentido da primeira. O mesmo ocorre na estrofe anterior. Na sexta estrofe, porém, apesar de também poderem ser agrupados de dois em dois, não são os versos pares que completam o sentido dos ímpares, mas sim os dois versos finais que completam o sentido dos dois iniciais.

Na sétima estrofe, encontramos uma particularidade com relação às demais: ela é a única em que há palavras proparoxítonas na rima (versos pares: céticas - poéticas). É a única também com uma rima formada por um hiato (versos ímpares: saparia - poesia). Encontramos algumas relações sonoras dentro dessa estrofe. Dividindo-a em versos iniciais versus finais, temos algumas relações entre eles. Por exemplo, as palavras finais dos dois primeiros versos se iniciam pela mesma consoante: [s]. Já as palavras finais dos dois últimos se iniciam por [p]. No primeiro verso, encontramos a palavra clame, iniciada por [kl] e no segundo verso, a palavra críticas, iniciada por [kr]. Estes encontros consonantais são muito semelhantes e tanto [1] quanto [r] ${ }^{7}$ são consoantes chamadas "líquidas". Nos dois últimos versos, há duas palavras monossílabas iniciadas por nasais (ñão e $\underline{\boldsymbol{m}}$ ais) em posição igualmente inicial. Em seguida, está a palavra há que ocorre nos dois versos, exatamente na mesma posição. As palavras mais (verso 3) e mas (verso 4) são muito semelhantes (e até mesmo pronunciadas da mesma maneira em alguns dialetos) e, assim, entram na lista das analogias sonoras nessa estrofe. Além disso, elas ocorrem em posições inversas: mais ocorre na terceira sílaba poética, logo após há; e mas ocorre na primeira sílaba poética, imediatamente antes de há. Uma última consideração diz respeito ao som [z] nos dois últimos versos. No verso 3, esse som aparece em poesia [poezia] (final do verso) e no verso 4, ele aparece em mas há [ma'za], no início do verso. Outra peculiaridade dessa estrofe é o ritmo. Existe uma regularidade a esse respeito nos três últimos versos, pois todos possuem as mesmas sílabas acentuadas. Interessante é ressaltar que esses fatores do plano da expressão que singularizam essa estrofe corroboram o que ela "diz" em seu conteúdo: Não há mais poesia / Mas há artes poéticas..., o que mostra a importância da forma para os parnasianos de forma conclusiva, já que é a última estrofe da sua "fala".

$\mathrm{Na}$ estrofe 9, o coaxar do sapo-boi é mais uma vez interrompido pelo sapotanoeiro. Aqui, ele vai continuar defendendo o verso bem medido, ou bem martelado. Comparando a grande arte (aqui, a poesia) ao lavor de joalheiro, ele intensifica e reitera a idéia de que a poesia deve ser um trabalho minucioso com a forma. Esta idéia continua na

\footnotetext{
${ }^{7}$ Chamado, em fonologia, de "tepe".
} 
estrofe seguinte (10) na qual o trabalho com a poesia é também comparado ao trabalho de um escultor (bem de estatuário), ou seja, que a beleza dos versos está diretamente ligada à forma e ao trabalho minucioso e demorado (canta no martelo) em busca de perfeição. E, justamente nessa décima estrofe que retoma a idéia do verso "perfeito", ocorrem algumas correspondências muito significativas no que diz respeito à matéria fônica. Por exemplo, nos três primeiros versos, há uma simetria na quantidade de consoantes surdas e sonoras: três de cada tipo. No verso 1, a seqüência em que elas aparecem é [b], [d], [r] e no verso 2 é [d], [b], [1]. Assim, nota-se uma construção em quiasmo entre as consoantes [b] e [d] e um paralelismo entre [r] e [1], ambas consoantes alveolares e também conhecidas (como já mencionamos) como "líquidas". No último verso, são 4 as consoantes sonoras: [n], [m], [r], [1], nesta ordem. O par [m, n] compartilha o mesmo modo de articulação (são nasais); e novamente encontramos [r, 1], que já descrevemos anteriormente. Passando às consoantes surdas, observa-se que são três, também, as ocorrências no verso 4. Outro ponto a observar é a presença da consoante surda [t]: duas ocorrências em cada um dos quatro versos. Nos dois versos seguintes, observamos a repetição paralela da expressão Tudo quanto é, que traz as consoantes surdas $[\mathrm{t}],[\mathrm{k}],[\mathrm{t}]$, ao passo que o último verso traz as mesmas consoantes na palavra canta, porém na ordem $[\mathrm{k}],[\mathrm{t}],[\mathrm{t}]$. Há um rima interna formada pela sequiência quanto, quanto, canta, dada pela repetição dos sons que já descrevemos e também pela repetição da nasal -an. Além dessas correspondências, notamos que a palavra final do verso 1 está semanticamente ligada à palavra final do verso 2 (estatuário - martelo), dado que o martelo é o instrumento de trabalho do estatuário). Por fim, do ponto de vista do ritmo, os três últimos versos têm a primeira sílaba acentuada. Voltemos à estrofe 9: sintaticamente, ocorre a mesma coisa que já ocorreu outras vezes nesse texto: a inversão de Sujeito + Verbo para Verbo + Sujeito, no verso 1. Mais uma vez podemos agrupar os versos de dois em dois com os finais completando sentido dos iniciais. Esse procedimento, aliás, conforme observamos, repete-se várias vezes ao longo do poema, bem como se repete a pontuação. $\mathrm{O}$ esquema é: dois versos seguidos de dois pontos e uma conclusão em seguida, em mais dois versos. Isto ocorre nas estrofes $2,3^{8}, 6,7,8^{9}, 9$. A partir da estrofe 10 , porém, esse esquema não mais ocorre e acontecem outras peculiaridades. Por exemplo, o primeiro verso da estrofe 10 está ligado ao último da estrofe nove, por uma alternância. Sintaticamente, ele se separa dos demais versos dessa estrofe e os três outros é que se relacionam numa única proposição. A proposição, por sua vez, serve para explicar o que se disse anteriormente com os outros três versos. Esquecendo a divisão em estrofes, podemos agrupar esses seis versos da seguinte maneira:

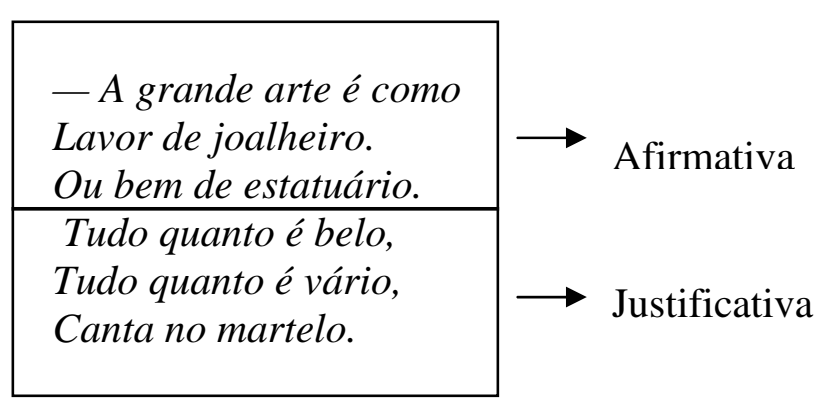

Figura 8

\footnotetext{
${ }^{8}$ Há, porém, uma pequena diferença na estrofe 3, pois a palavra inicial do terceiro verso ainda faz parte da proposição encerrada nos dois versos anteriores.

${ }^{9}$ Apesar de a oitava estrofe ter um verso a menos.
} 
Ainda com relação aos possíveis agrupamentos dos versos, a estrofe 11 traz os três primeiros relacionados em uma só proposição (diferente do que estava ocorrendo na maioria dos casos, onde tínhamos dois versos), seguidos de dois pontos e do último verso que completa o sentido da proposição. Acerca das estrofes de 12 a 14, falaremos mais adiante. Voltando à sonoridade, o que encontramos de peculiar na estrofe 11 é o último verso, que, assim, como outros versos das estrofes dois e oito, lembra o coaxar dos sapos, dados pela alternância de silabas tônicas e átonas e pela repetição de palavras: - "Sei!" - "Não sabe!" "Sabe!".

A partir da estrofe de número 12 é que se inicia o trecho em que o narrador conta a situação do sapo-cururu, metáfora do poeta não-parnasiano. $\mathrm{Na}$ estofe 12 , longe (verso 1) e lá onde (verso 2) formam uma rima interna. É grande também a quantidade de nasais, conforme destacamos na transcrição abaixo:

\section{Longe dessa grita, Lá onde mais densa A noite infinita Verte a sombra imensa;}

A recorrência de tais nasais ajuda a criar um tom melancólico, diferente do tom exaltado dos versos referentes aos demais sapos. Observe-se, ainda, que o sapo-tanoeiro primeiro diz, depois brada. O sapo-boi primeiramente ronca e depois urra. E até o sapo-pipa fala, ao passo que o sapo-cururu (como se vê na última estrofe) apenas soluça. As nasais também reforçam a imagem de distância (longe, na noite densa) e isolamento do sapo-cururu. A rima nos versos pares é formada por adjetivos, sendo que densa qualifica noite, e imensa qualifica sombra. Os quatro versos devem ser vistos como uma só proposição. Na verdade, observando os versos da estrofe seguinte e considerando que sei último verso $\left(12^{\circ}\right)$ termina por ponto e vírgula (e não por ponto final ou exclamações como nas demais estrofes) e o último verso da estrofe 13 termina sem pontuação (o que não havia ocorrido até então), podemos pensar num agrupamento de todos os nove versos, como se eles compusessem um grande período. Essa ligação entre as estrofes é bastante clara na passagem da 13 para a 14: $E$ solitário, é / Que soluças tu. Uma outra coisa que corrobora esta análise é o fato de não haver verbos na estrofe 13 (a intermediária das três). Portanto, em termos de conteúdo não há motivo para separar esses versos e eles só são divididos em estrofes para obedecer a uma regularidade formal.

A décima terceira estrofe apresenta a solidão do sapo-cururu e traz o verso $E$ solitário é, que é o único verso de 6 sílabas em todo o poema. Justamente o verso que expressa a solidão e traz a palavra solitário está sozinho no poema no que diz respeito à métrica, uma vez que, como já mencionamos, todos os outros versos são pentassílabos. Isso reitera a solidão do sapo-cururu. Uma relação entre os versos 1 e 3 é que ambos apresentam um lugar (lá e perau), respectivamente. Entre os versos 2 e 4 podemos identificar uma redundância semântica, se considerarmos que solitário é o mesmo que sem ninguém, o que formaria uma série com sem glória, sem fé.

Assim, constatamos, até o momento, que todas as estrofes correspondentes à fala do sapo-tanoeiro, que no poema é uma metáfora do poeta parnasiano, são de uma grande complexidade na estruturação de seus elementos formais. O que o poeta "faz" no plano da expressão é o que o poeta parnasiano faz. O poema, no que diz respeito à expressão (e em alguns aspectos ao conteúdo), encaixa-se nos moldes parnasianos. A regularidade da métrica e da rima bem como a grande preocupação com sonoridade demonstram uma preocupação 
extremada com a forma. Concluímos que o enunciador faz no plano da expressão o que nega, por meio da ironia, no plano do conteúdo.

Considerando o livro Carnaval como um todo, constatamos que a preocupação com a forma é menor do que a que se vê no livro anterior (A Cinza das Horas), embora continuem existindo em grande quantidade poemas com métrica e rimas regulares (há apenas três poemas com versos livres). O ritmo, porém, conforme já comentamos, começa a ficar mais "livre" a partir desse livro. Tanto palavras complexas quanto simples são utilizadas, há muitos poemas que se referem ao cotidiano e há até mesmo um poema em prosa ("Epígrafe"). Aproveitando o quadrado semiótico acima e tendo em mente a idéia de que Carnaval é um livro de transição, podemos afirmar que o livro em seu conjunto, assim como o sapo-cururu de "Os Sapos", situa-se numa fase de negação de valores preexistentes, em direção à afirmação de outros. Ou seja, Carnaval está também na posição de "não-S1" (não-integração, contenção, não-continuidade, não-conjunção, não-parnasianismo.

Um exemplo de poema que preserva rima, métrica e ritmo regulares é “A Rosa", do qual transcrevemos um trecho:
A vista incerta,
Os ombros langues,
Pierrot aperta
As mãos exangues
De encontro ao peito
(...)

Esse poema é composto por rimas regulares do tipo $\mathrm{ABABC}$ em todas as sete estrofes de cinco versos cada uma. A métrica também é regular: há quatro sílabas em cada verso. O ritmo pode se diferenciar entre as estrofes, mas é sempre regular dentro de uma mesma estrofe. Na estrofe transcrita, por exemplo, a acentuação ocorre sempre na segunda e na quarta sílaba, mas há estrofes com a acentuação na primeira e na quarta.

Para exemplo de um poema com variação rítmica, transcrevemos um trecho de "Bacanal":

Quero beber! cantar asneiras

No esto brutal das bebedeiras

Que tudo emborca e faz em caco

Evaoé Baco!

Lá se me parte a alma levada

No torvelim da mascarada,

A gargalhar em doudo assomo...

Evaoé Momo!

Lacem-na toda, multicores,

As serpentinas dos amores,

Cobras de lívidos venenos...

Evaoé Vênus!

(...) 
CASA, Vol.5, n.2, dezembro de 2007

incomuns:

No poema "A Ceia" encontramos um exemplo de utilização de palavras

Junto à púrpura os tons mais ricos esmaecem.

Chispa ardente lascívia em cada rosto glabro

(...)

Quando em volúpia aos mais os olhos enlanguescem,

Os seus, frios, fitando o irmão, lançá-lo tecem,

Horas depois, do Tibre ao fundo voluntabro.

(...)

Como exemplo de poema com versos livres (e também sem ritmo e métrica regulares), transcrevemos a seguir alguns versos de "Toante":

Molha em teu pranto de aurora as minhas mãos pálidas.

Molha-as. Assim eu as quero levar à boca,

Em espírito de humildade, como um cálice

De penitência em que a minh'alma se faz boa...

Foi assim que Teresa de Jesus amou...

(...)

O último exemplo que daremos é o poema "Vulgívaga" que ilustra uma situação do cotidiano e faz uso de um vocabulário bastante simples. O poema conta a história da vida sexual de uma mulher:

Não posso crer que se conceba

Do amor senão o gozo físico!

O meu amante morreu bêbado,

E meu marido morreu tísico!

(...)

Fui de um... Fui de outro... Este era médico...

Um, poeta... Outro, nem sei mais!

Tive em meu leito enciclopédico

Todas as artes liberais.

(...)

Visto como um primeiro "grito de libertação" em meio a uma poesia presa pela forma, o poema critica esse aprisionamento (da poesia, da inspiração, do lirismo) por regras e formas preestabelecidas e faz uma crítica ao Parnasianismo. Além disso, o poema foi lido na Semana de Arte Moderna de 1922, importante evento do Modernismo no Brasil. 
CASA, Vol.5, n.2, dezembro de 2007

\section{Referências bibliográficas}

BANDEIRA, Manuel. Itinerário de Pasárgada. Rio de Janeiro: Nova Fronteira, 1984. Estrela da vida inteira. Rio de Janeiro: Nova Fronteira, 1993.

BARROS, Diana Luz Pessoa de. Teoria do discurso: fundamentos semióticos. São Paulo: Humanitas, 2001.

_. Teoria semiótica do texto. São Paulo: Ática, 2003.

BERTRAND, Denis. Caminhos da semiótica literária. Trad. Grupo CASA. Bauru, SP: EDUSC, 2003.

BILAC, Olavo. Poesias. São Paulo: Martins Fontes, 1996.

BRANDÃO. Roberto de Oliveira. Poemas sobre a poesia na literatura brasileira. São Paulo: USP (Tese de Livre Docência), 1992.

DISCINI, Norma. Intertextualidade e conto maravilhoso. São Paulo: Humanitas, 2004.

FIORIN, José Luiz. As astúcias da enunciação. São Paulo: Ática, 1996.

_. Elementos de análise do discurso. São Paulo: Contexto, 2005.

FONTANILLE, Jacques; ZILBERBERG, Claude. Tensão e significação. Trad. Ivã Carlos Lopes; Luiz Tatit; Waldir Beividas. São Paulo: Discurso Editorial/Humanitas, 2001.

JAKOBSON, Roman. Lingüística. Poética. Cinema. São Paulo: Perspectiva, 2004.

GARBUGLIO, José Carlos. "Lirismo e coerção social”. In: LOPES, Telê Porto Ancona (org). Manuel Bandeira: verso e reverso. São Paulo: TAQ, 1987.

GOLDSTEIN, Norma (org). Traços marcantes no percurso poético de Manuel Bandeira. São Paulo: Humanitas, 2005.

GREIMAS, Algirdas Julien; COURTÉS, Joseph. Dicionário de semiótica. São Paulo: Cultrix, 1983.

_. Sémiotique: dictionnaire raisonné de la théorie du langage-II. Paris: Hachette, 1986.

HOUAISS, Antônio; VILLAR, Mauro de Salles. Minidicionário Houaiss da Língua Portuguesa. Rio de Janeiro: Objetiva, 2004.

LOPES, Ivã Carlos; HERNANDES, Nilton (orgs.). Semiótica: objetos e práticas. São Paulo: Contexto, 2005.

MOURA, Murilo Marcondes. Manuel Bandeira. São Paulo: Publifolha, 2001. 
CASA, Vol.5, n.2, dezembro de 2007

SOCIEDADE BÍBLICA DO BRASIL. Bíblia Sagrada: nova tradução na linguagem de hoje. Barueri, 2000.

TATIT, Luiz. Análise semiótica através das letras. São Paulo: Ateliê Editorial, 2001.

ZILBERBERG, Claude. “As condições semióticas da mestiçagem”. In: CAÑIZAL, Eduardo Peñuela; CAETANO, Kati. (orgs.). O Olhar à deriva: mídia, significação e cultura. Trad. LOPES, Ivã Carlos; TATIT, Luiz. São Paulo: Annablume, 2004.

Razão e poética do sentido. Trad. Ivã Carlos Lopes; Luiz Tatit; Waldir Beividas. São Paulo: Edusp, 2006.

. Seuils, limites, valeurs. Disponível em <http://www.claudezilberberg.net $>$ - acessso em 01 Jun 2007. 


\section{ANEXOS}

\section{Profissão de Fé}

Olavo Bilac

Le poète est ciseleur,

Le ciseleur est poète.

(Victor Hugo)

Não quero o Zeus Capitolino

Hercúleo e belo,

Talhar no mármore divino

Com o camartelo.

Que outro - não eu! - a pedra corte Para, brutal,

Erguer de Atene o altivo porte

Descomunal.

Mais que esse vulto extraordinário,

Que assombra a vista,

Seduz-me um leve relicário

De fino artista.

Invejo o ourives quando escrevo:

Imito o amor

Com que ele, em ouro, o alto relevo

Faz de uma flor.

Imito-o. E, pois, nem de Carrara

A pedra firo:

$\mathrm{O}$ alvo cristal, a pedra rara,

$\mathrm{O}$ ônix prefiro.

Por isso, corre, por servir-me,

Sobre o papel

A pena, como em prata firme

Corre o cinzel.

Corre; desenha, enfeita a imagem,

A idéia veste:

Cinge-lhe ao corpo a ampla roupagem

Azul-celeste.

Torce, aprimora, alteia, lima

A frase; e, enfim,

No verso de ouro engasta a rima,

Como um rubim.
Quero que a estrofe cristalina,

Dobrada ao jeito

Do ourives, saia da oficina

Sem um defeito:

E que o lavor do verso, acaso,

Por tão subtil,

Possa o lavor lembrar de um vaso

De Becerril.

E horas sem conto passo, mudo,

O olhar atento,

A trabalhar, longe de tudo

$\mathrm{O}$ pensamento.

Porque o escrever - tanta perícia,

Tanta requer,

Que oficio tal... nem há notícia

De outro qualquer.

Assim procedo. Minha pena

Segue esta norma,

Por te servir, Deusa serena,

Serena Forma!

Deusa! A onda vil, que se avoluma

De um torvo mar,

Deixa-a crescer; e o lodo e a espuma

Deixa-a rolar!

Blasfemo em grita surda e horrendo

Ímpeto, o bando

Venha dos bárbaros crescendo,

Vociferando...

Deixa-o: que venha e uivando passe

- Bando feroz!

Não se te mude a cor da face

E o tom da voz! 
Olha-os somente, armada e pronta, Radiante e bela:

E, ao braço o escudo a raiva afronta Dessa procela!

Este que à frente vem, e o todo Possui minaz

De um vândalo ou de um visigodo, Cruel e audaz;

Este, que, de entre os mais, o vulto Ferrenho alteia,

E, em jato, expele o amargo insulto Que te enlameia:

É em vão que as forças cansa, e â luta Se atira; é em vão Que brande no ar a maça bruta A bruta mão.

Não morrerás, Deusa sublime!

Do trono egrégio

Assistirás intacta ao crime

Do sacrilégio.

E, se morreres por ventura, Possa eu morrer

Contigo, e a mesma noite escura Nos envolver!

Ah! ver por terra, profanada, A ara partida

E a Arte imortal aos pés calcada, Prostituída!...

Ver derribar do eterno sólio O Belo, e o som

Ouvir da queda do Acropólio, Do Partenon!...
Sem sacerdote, a Crença morta

Sentir, e o susto

Ver, e o extermínio, entrando a porta

Do templo augusto!...

Ver esta língua, que cultivo,

Sem ouropéis,

Mirrada ao hálito nocivo

Dos infiéis!...

Não! Morra tudo que me é caro, Fique eu sozinho!

Que não encontre um só amparo

Em meu caminho!

Que a minha dor nem a um amigo Inspire dó...

Mas, ah! que eu fique só contigo,

Contigo só!

Vive! que eu viverei servindo

Teu culto, e, obscuro,

Tuas custódias esculpindo

No ouro mais puro.

Celebrarei o teu oficio

No altar: porém,

Se inda é pequeno o sacrifício,

Morra eu também!

Caia eu também, sem esperança, Porém tranqüilo,

Inda, ao cair, vibrando a lança, Em prol do Estilo! 